\title{
MAIN ASPECTS OF USING MULTILAYER POLYMERIC MATERIALS FOR PASTERIZATION AND STERILIZATION OF PRODUCTS IN THE MEAT PROCESSING INDUSTRY
}

\author{
V. Pasichnyi, A. Ukrainets, O. Khrapachov, A. Marynin \\ National University of Food Technologies
}

\begin{tabular}{l}
\multicolumn{1}{c}{ Key words: } \\
Meat and meat products \\
Packing materials \\
Pasteurization \\
Sterilization \\
Storage term \\
Guaranteed quality \\
Microbiological stability \\
\hline \multicolumn{1}{c}{ Article history: } \\
Received 23.07.2018 \\
Received in revised form \\
06.08.2018 \\
Accepted 22.08.2018 \\
\hline Corresponding author: \\
V. Pasichnyi \\
E-mail: \\
npnuht@ukr.net
\end{tabular}

ABSTRACT

The main purpose of the research is to study the structure of multilayer polymeric materials offered at the domestic and foreign markets for the manufacture of pasteurized and sterilized meat products to improve manufacturing processes and to develop the recommendations for the most relevant structures of polymeric multilayer films (packages) for use when manufacturing this type of product. Research methodology: quantitative and qualitative composition of the experimental multilayer polymer films and packages was checked. Packaged test samples of meat products were investigated by the structural and mechanical characteristics; it has been checked the change of organoleptic parameters before and after repeated heat treatment (pasteurization), water activity, microbiological research, dependence of these indicators on the content of the main raw material in the product.

Results: recommendations about the technology of production of this type of products, packing conditions, choice of packaging materials, and revision of storage periods have been developed.

Conclusions: it is important to review the terms of storage of pasteurized meat products in accordance with the current normative documentation with the purpose of their prolongation or the development of new normative and technological documentation; to select the packaging materials with the best characteristics to ensure a stable storage term of products, resistant to high temperatures, having good mechanical and high barrier properties; to take into account that when exposed to temperatures near $100^{\circ} \mathrm{C}$, it is also necessary to use glue for the lamination and inks for printing that are resistant to high temperatures and used to sterilize the product at temperatures above $100^{\circ} \mathrm{C}$; for certain types of products, in order to keep the guaranteed good appearance of the product, peeling is required before its packaging and making a repeated heat treatment or manufacture of such a product without shell. This is due to the breaking of the shell in the process of pasteurization or sterilization of the packed product.

The production of pasteurized and sterilized meat products is a promising area in the meat processing industry, which substantiates the relevance of scientific research in this area with the purpose of introducing new high-tech products that will be competitive not only on the Ukrainian but also on the European market.

DOI: $10.24263 / 2225-2924-2018-24-4-22$ 


\title{
ОСНОВНІ АСПЕКТИ ВИКОРИСТАННЯ БАГАТОШАРОВИХ ПОЛІМЕРНИХ МАТЕРІАЛІВ ДЛЯ ПАСТЕРИЗАЦІЇ ТА СТЕРИЛІЗАЦІЇ ПРОДУКЦІЇ В М'ЯСОПЕРЕРОБНІЙ ГАЛУЗІ
}

\author{
B.М. Пасічний, А.І. Українець, О.В. Храпачов, А.І. Маринін \\ Національний університет харчових технологій
}

Основною метою досліджень є вивчення структур багатошарових полімерних матеріалів, що пропонуються на вітчизняному та зарубіжноному ринках для виготовлення пастеризованих і стерилізованих м'ясопродуктів з метою вдосконалення процесів виробництва иих продуктів та розробки рекомендаиій щодо найбільш актуальних структур полімерних багатошарових плівок (пакетів) для використання при виготовленні. Був перевірений кількісний та якісний склад дослідних багатошарових полімерних плівок і пакетів. Запаковані тестові зразки м'ясопродуктів були досліджені за структурномеханічними властивостями. Перевірені: зміна органолептичних показників до та після повторної термічної обробки (пастеризачії), активність води, мікробіологічні дослідження, залежність показників від вмісту основноі сировини в продукті.

У результаті розроблені рекомендаиії щодо технології виробництва иього виду продуктів, умов пакування, вибору пакувальних матеріалів, перегляду термінів зберігання для пастеризованих і стерилізованих м'ясопродуктів, який є перспективним напрямком у м'ясопереробній галузі й обтрунтовує актуальність наукових досліджень иього напряму не тільки на украӥнському, але й на європейському ринках.

Ключові слова: м'ясо та м'ясопродукти, пакувальні матеріали, пастеризачія, стерилізація, термін зберігання, гарантована якість, мікробіологічна стабільність.

Постановка проблеми. 3 відкриттям кордонів для вітчизняних м'ясопродуктів в умовах євроінтеграції стає все більш актуальним збільшення термінів зберігання м'ясопродуктів. Це нерозривно пов'язано з метою запобігання втрат при зберіганні продукції, для збереження якісних характеристик продукту, його захистом від негативного впливу мікроорганізмів при виробництві та зберіганні, та розгалуженим ланцюгом логістики. При цьому актуальним питанням $є$ системне забезпечення якості та безпеки харчової продукції, що обумовлює необхідність впровадження комплексних заходів, спрямованих на підвищення даних показників.

Акцентуючи увагу виробників м'ясопродуктів на актуальності питання, слід зазначити, що його реалізація можлива при вивченні пакувальних полімерних матеріалів; процесів, які відбуваються при виробництві, пакуванні та зберіганні продукції; можливості комбінування систем пакування, виходячи 3 характеристик, які необхідно надати тому чи іншому продукту. 
Важливим фактором, здатним суттєво вплинути на вищезгадані показники, $є$ повторна термічна обробка запакованого продукту у вигляді пастеризації або стерилізації, яка є можливою за умови використання багатошарових полімерних матеріалів 3 чітко визначеними характеристиками.

Серед широкого спектра багатошарових полімерних матеріалів можна виділити такі, що використовуються для пакування готової продукції під вакуумом або в модифікованому газовому середовищі, проведення заморожування, теплової обробки продукції (запікання, пастеризації, стерилізації тощо), та комбіновані матеріали, які можуть об’єднувати декілька функцій (наприклад, пастеризацію та заморожування). Виготовленням таких матеріалів займаються як зарубіжні компанії, так і професійні вітчизняні виробники, що мають спеціалізацію на виробництві багатошарових пакетів або полімерних плівок, пропонуючи виробникам м'ясопродуктів сучасні інноваційні рішення [1].

Асортимент полімерних матеріалів досить різноманітний, але дуже структурований залежно від заданих характеристик, які і дають змогу отримати якісний кінцевий продукт. 3 огляду на асортимент м'яких бар'єрних полімерних плівок для упаковки м'ясопродуктів їх можна розподілити за основною базовою структурою: PA/PE, PA/PP/PE, які неодноразово чергуються між собою. РА (поліамід) є бар'єрним шаром (для середнього бар'єру), бере участь у процесі формування нижньої плівки. РР (поліпропілен) впливає на прозорість, глянець і механічні характеристики плівки, може бути зварним шаром (якщо $є$ зовнішнім). PE (поліетилен) служить для наповнення товщини плівки i, якщо є зовнішнім шаром, служить як зварний шар [2; 3]. Зазначені складові полімерних плівок також можуть значно відрізнятись між собою залежно від їх функцій та умов використання самих плівок. Поліетиленова плівка практично водонепроникна, тому при зберігання в ній продукції майже не відбувається всихання продукту. Характеристики цієї плівки практично не змінюються в температурних межах від -50 до $+70^{\circ} \mathrm{C}$, але вона не має бар'єрних властивостей [4; 5]. Наприклад, $€$ марки поліпропілену, які не можна заморожувати задля запобігання розтріскування (розгерметизації) упаковки, але серед його переваг можна відзначити порівняно високі механічні властивості, прозорість, глянець, витривалість до дії високих температур $\left(120-130^{\circ} \mathrm{C}\right)$, тому і використовується зварний шар для плівок, які призначені для високотемпературної обробки продукту (більше $100^{\circ} \mathrm{C}$ ). С марки, які дуже добре переносять як дію низьких, так і вплив високих температур. Комбінування та склад пакувальних матеріалів залежать від умов $\mathrm{i}$ технології їх виготовлення та вимог виробників м'ясопродуктів щодо функціональності самих плівок чи пакетів [6].

У складі плівок з високим значенням бар'єрності використовується екологічно нешкідливий EVOH (сополімер етиленвінілового спирту), який піддається переробці та вторинному використанню і на відміну від PVDC не містить хлору і діоксину, що порушують ендокринну систему людини.

Як надійний асептичний бар'єр для бактерій і кисню EVOH сприяє подовженню терміну зберігання виробів у процесі транспортування і при зберіганні. Це, у свою чергу, дає змогу виробнику знизити концентрацію консервантів у харчовому продукті або навіть відмовитись від них [3; 7]. 
При виборі верхньої плівки для термоформувальних ліній перевагу надають ламінованому матеріалу, який менш вибагливий до перепадів температур на станції зварювання, має належні оптичні характеристики (прозорість, глянець) та ідеально підходить для нанесення міжшарового друку. Для термічної обробки продукції в упаковці для пастеризації (за температури близько $85^{\circ} \mathrm{C}$ ) або стерилізації (за температури близько $120^{\circ} \mathrm{C}$ ) в складі багатошарових плівок використовують спеціальний клей під ламінацію [8].

При збільшенні терміну зберігання готових м'ясопродуктів використовують додаткову термічну обробку після процесу ії пакування: пастеризацію або стерилізацію. Одним з прикладів пастеризованого продукту є ковбаси варені, сосиски, сардельки, в тому числі з м'яса птиці, що виготовляються згідно з чинною в Україні нормативно документацію.

Повторне температурне оброблення продукції відбувається за формулою $(20-(20-60)-10)$ хв при $90-95^{\circ} \mathrm{C}$. Також виробляють стерилізовані в полімерній упаковці шинки за температури $115^{\circ} \mathrm{C}[8]$.

Мета дослідження: вивчення структур багатошарових полімерних матеріалів, що пропонуються на вітчизняному та зарубіжному ринках для виготовлення м'ясопродуктів з подальшою їх пастеризацією або стерилізацією з метою вдосконалення процесів виробництва цих продуктів та розроблення рекомендацій щодо найбільш актуальних структур полімерних багатошарових плівок (пакетів) для використання при виготовленні даного виду продукції, яка буде конкурентною не тільки на українському, але й на європейському ринку.

Матеріали і методи. Серед зразків полімерних плівок і продукції, що була в них запакована (в тому числі тестових зразків у трьох повторах), були використані декілька варіантів пакування, вироблених в Італії, Польщі, Германії, Ізраїлі, а саме:

- сосиски пастеризовані виробництва Італії з терміном зберігання до трьох місяців при температурі $2-4^{\circ} \mathrm{C}$ (рис. 1 );

- сосиски пастеризовані виробництва Італія, які мають термін зберігання 45 діб за умови зберігання при температурі $2-4^{\circ} \mathrm{C}$;

- сосиски виробництва Ізраїль, які мають термін зберігання 45 діб за умови зберігання при температурі $2-4^{\circ} \mathrm{C}$;

- тестові зразки сосисок, вироблених в Україні з використанням двох плівок - 3 нижньою прозорою плівкою і верхньою для нанесення друку (рис. 8).

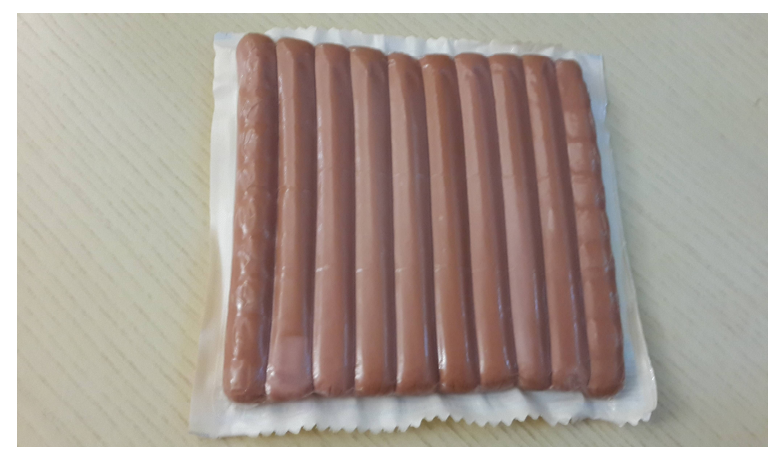

Рис. 1. Упаковка сосисок пастеризованих (Італія) 
Результати і обговорення. На рис. 2 і 3 представлено досліджені характеристики пакувальних матеріалів виробництва Італії. Упаковка сосисок виробництва Італії складається з двох плівок: нижньої прозорої, з якої сформований лоток для укладання продукту (на рис. 2 зображений іï зріз під мікроскопом, на рис. 3 - ДСК-графік ії дослідження.

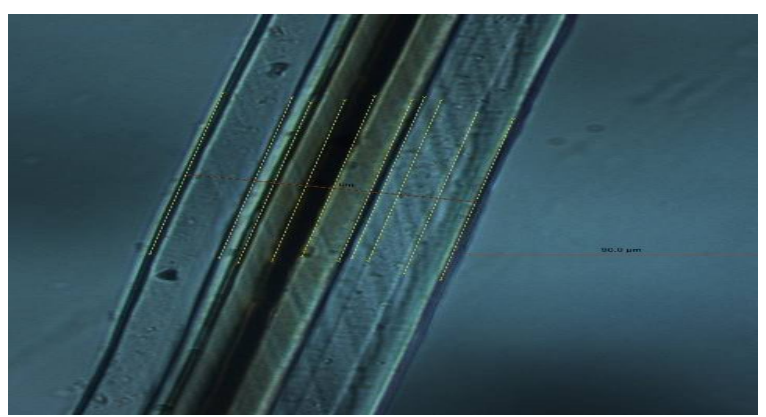

Рис. 2. Зріз під мікроскопом багатошарової плівки для пастеризації (Італія)

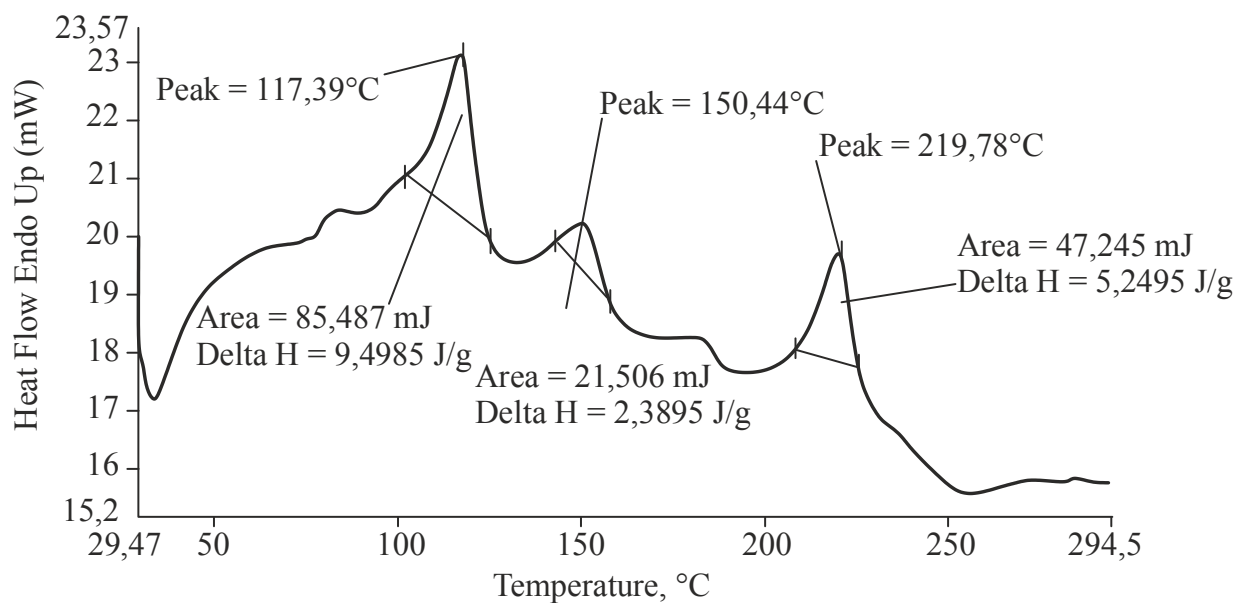

Рис. 3. ДСК-графік багатошарової плівки для пастеризації виробництво (Італія)

У табл. 1 представлено склад плівки виробництва Італія для зберігання ковбасних виробів до трьох місяців.

Таблиця 1. Склад багатошарової плівки для пастеризації виробництва (Італія)

\begin{tabular}{|c|c|c|c|c|c|}
\hline Назва матеріалу & $\begin{array}{c}\text { Густина шару, } \\
\text { гр/м }{ }^{3}\end{array}$ & $\begin{array}{c}\text { Товщина } \\
\text { шару, мкм }\end{array}$ & Маса шару & $\begin{array}{c}\text { Відсоток шару } \\
\text { за об’ємом, \% }\end{array}$ & $\begin{array}{c}\text { Відсоток шару } \\
\text { за масою, \% }\end{array}$ \\
\hline 1 & 2 & 3 & 4 & 5 & 6 \\
\hline PP & 0,900 & 20,61 & 18,55 & 23,57 & 21,35 \\
\hline Adhesive layer & 0,926 & 6,06 & 5,61 & 6,93 & 6,46 \\
\hline PA & 1,140 & 9,58 & 10,92 & 10,96 & 12,57 \\
\hline EVOH & 1,170 & 8,10 & 9,48 & 9,26 & 10,91 \\
\hline PA & 1,140 & 11,26 & 12,84 & 12,88 & 14,78 \\
\hline Adhesive layer & 0,926 & 3,26 & 3,02 & 3,73 & 3,48 \\
\hline
\end{tabular}




\begin{tabular}{|c|c|c|c|c|c|}
\hline 1 & 2 & 3 & 4 & 5 & 6 \\
\hline РЕ & 0,926 & 5,25 & 4,86 & 6,00 & 5,60 \\
\hline РЕ & 0,926 & 11,95 & 11,07 & 13,67 & 12,74 \\
\hline РЕ зварний & 0,926 & 11,43 & 10,52 & 12,99 & 12,11 \\
\hline РАЗОМ: & - & 87,43 & - & 100,00 & 100,00 \\
\hline
\end{tabular}

На рис. 4 представлено зріз під мікроскопом верхньої плівки 3 міжшаровим друком сосисок пастеризованих виробництва Італія, які мають термін зберігання 45 діб за умови зберігання при температурі $2-4^{\circ} \mathrm{C}$. ДСК-графік іiі дослідження і склад плівки наведено на рис. 5 і в табл. 2.

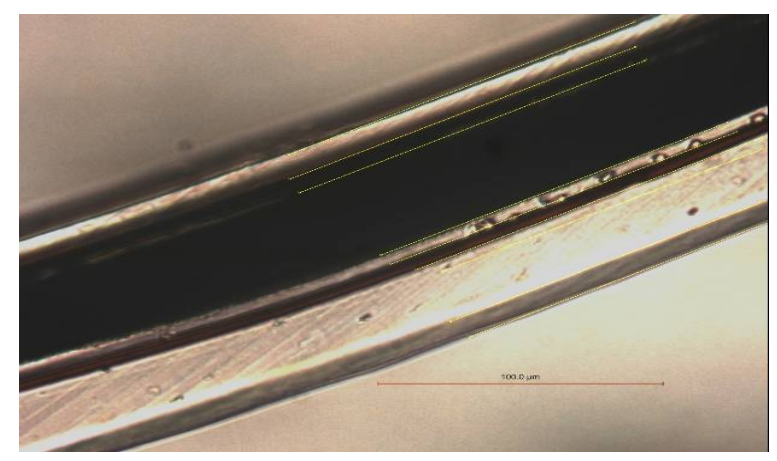

Рис. 4. Зріз під мікроскопом багатошарової плівки для пастеризації 3 терміном зберігання до 45 діб (Італія)

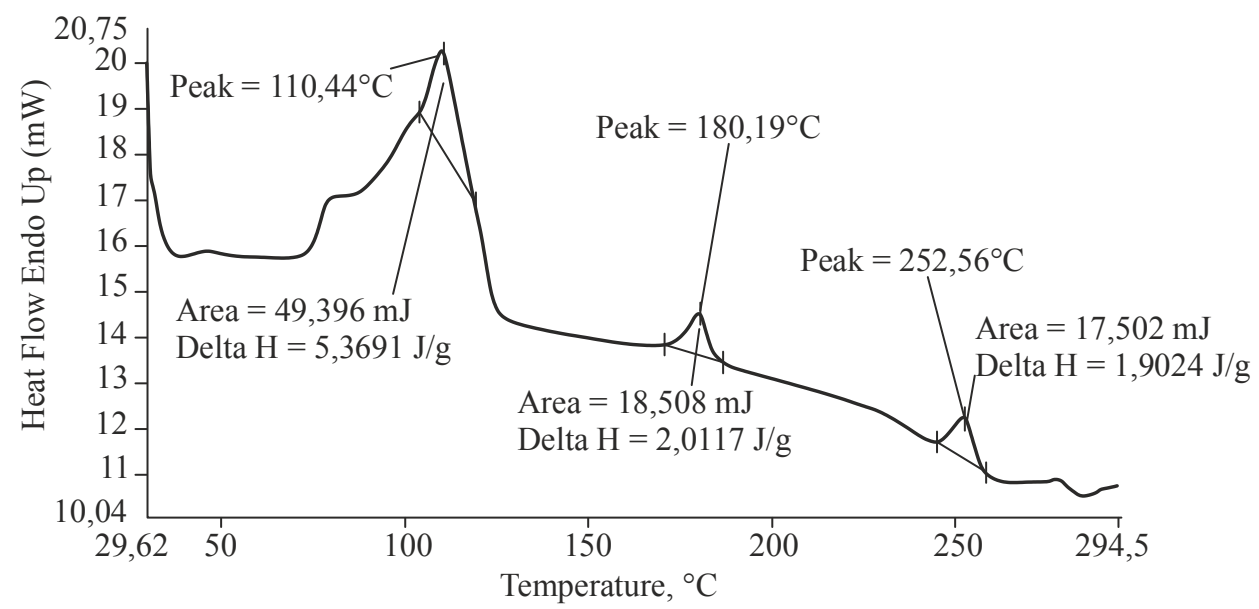

Рис. 5. ДСК-графік багатошарової плівки для пастеризації 3 терміном зберігання до 45 діб (Італія)

Таблиия 2. Склад багатошарової плівки для пастеризації з терміном зберігання до 45 діб (Італія)

\begin{tabular}{|c|c|c|c|c|c|}
\hline Назва матеріалу & $\begin{array}{c}\text { Густина } \\
\text { шару, гр/м }\end{array}$ & $\begin{array}{c}\text { Товщина } \\
\text { шару, мкм }\end{array}$ & $\begin{array}{c}\text { Маса } \\
\text { шару }\end{array}$ & $\begin{array}{c}\text { Відсоток шару } \\
\text { за об'ємом, \% }\end{array}$ & $\begin{array}{c}\text { Відсоток шару за } \\
\text { масою, \% }\end{array}$ \\
\hline 1 & 2 & 3 & 4 & 5 & 6 \\
\hline ВоРЕТ & 1,390 & 11,70 & 16,26 & 11,54 & 16,11 \\
\hline
\end{tabular}




\begin{tabular}{|c|c|c|c|c|c|}
\hline \multicolumn{5}{|c|}{ Продовження табл. 2 } \\
\hline Міжшаровий друк & 2 & 3 & 4 & 5 & 6 \\
\hline Glue & - & - & - & - & - \\
\hline PE білий & 0,926 & 7,20 & 6,67 & 7,10 & 6,60 \\
\hline Adhesive layer & 0,926 & 41,07 & 38,03 & 40,49 & 37,67 \\
\hline EVOH & 1,170 & 6,18 & 3,87 & 4,12 & 3,83 \\
\hline Adhesive layer & 0,926 & 3,81 & 7,76 & 6,54 & 7,68 \\
\hline PE & 0,926 & 16,50 & 15,28 & 16,27 & 3,49 \\
\hline PЕ зварний & 0,926 & 10,33 & 9,57 & 10,19 & 9,13 \\
\hline РАЗОМ: & - & 101,42 & - & 100,00 & 100,00 \\
\hline
\end{tabular}

Упаковка сосисок, вироблених в Ізраїлі (термін зберігання 45 діб), являє собою вакуумний пакет, дві сторони якого мають абсолютно ідентичні характеристики (на рис. 6 зображений зріз полотна пакета під мікроскопом, на рис. 7 - ДСК-графік його дослідження, а в табл. 3 наведено його склад).

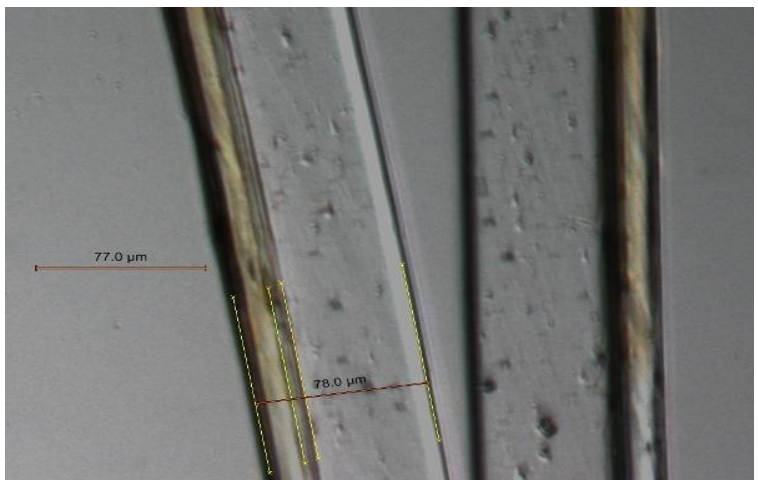

Рис. 6. Зріз під мікроскопом багатошарової плівки (у вигляді пакета) для пастеризації або стерилізації м'ясопродуктів (Ізраїль)

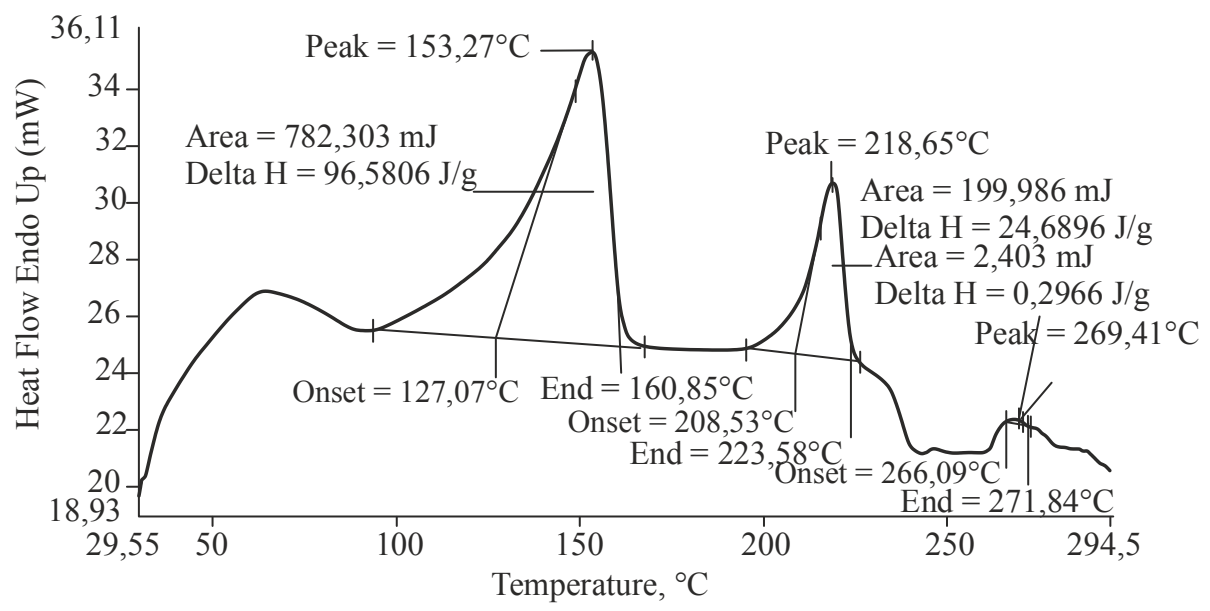

Рис. 7. ДСК-графік багатошарової плівки (у вигляді пакета) для пастеризації або стерилізації м'ясопродуктів (Ізраїль) 
Таблиия 3. Склад багатошарової плівки (у вигляді пакета) для пастеризації або стерилізації м'ясопродуктів (Ізраїль)

\begin{tabular}{|c|c|c|c|c|c|}
\hline Назва матеріалу & $\begin{array}{c}\text { Густина } \\
\text { шару, гр/м }\end{array}$ & $\begin{array}{c}\text { Товщина } \\
\text { мкм }\end{array}$ & $\begin{array}{c}\text { Маса } \\
\text { шару }\end{array}$ & $\begin{array}{c}\text { Відсоток шару } \\
\text { за об'ємом, \% }\end{array}$ & $\begin{array}{c}\text { Відсоток шару за } \\
\text { масою, \% }\end{array}$ \\
\hline PА & 1,140 & 16,51 & 18,82 & 21,08 & 25,22 \\
\hline Adhesive layer & 0,926 & 6,30 & 5,83 & 8,04 & 7,82 \\
\hline $\begin{array}{c}\text { РP + вторинна } \\
\text { сировина }\end{array}$ & 0,900 & 55,51 & 49,96 & 70,88 & 66,96 \\
\hline РАЗОМ: & - & 78,32 & - & 100,00 & 100,00 \\
\hline
\end{tabular}

Для визначення раціональних типів пакування були проведені тестові пакування пастеризованих сосисок і сардельок для розроблення продуктів тривалого зберігання.

Упаковка тестових зразків сосисок складалась із двох плівок: нижньої прозорої, з якої сформований лоток для укладання продукту, та верхньої плівки з можливістю нанесення друку.

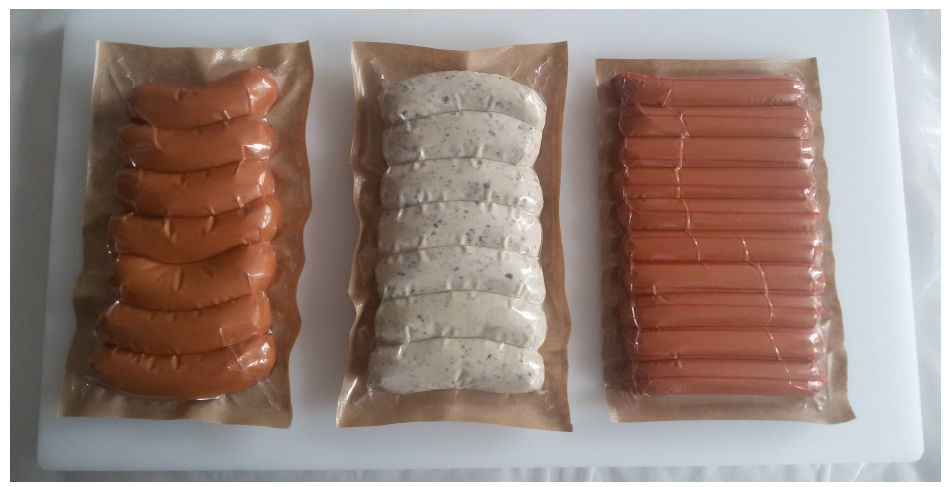

Рис. 8. Фото упаковки сосисок, сардельок пастеризованих (тестові зразки)

У процесі дослідження визначали сенсорні, структурно-механічні характеристики і бар'єрні властивості плівок у рекомендованих термінах зберігання при проведенні повторної пастеризації.

Було визначено, що зразки зарубіжних матеріалів відрізняються за своєю структурою та характеристиками. Найкращими за термінами зберігання виявився зразок, вироблений в Україні, та зразок з терміном зберігання до трьох місяців виробництва Італії, які мали підвищені механічні характеристики, високі бар'єрні властивості полімерних плівок.

Однак ці плівки мають температурні обмеження і непридатні для використання $з$ метою стерилізації продукції. Це пов'язано з наявністю в зварному шарі поліетилену та нетермостійкої фарби і клею для ламінації, які не витримують дію температур вище $95^{\circ} \mathrm{C}$.

Зразок плівки виробництва Ізраїль для проведення повторної пастеризації або стерилізації (табл. 3) завдяки наявності у зварному шарі поліпропілену дуже добре витримує дію високих температур, але запакована в ньому продукція мала невеликий (традиційний) термін зберігання через низькі бар'єрні характеристики плівки, з якої був виготовлений пакет. 
Як видно $з$ табл. 3, плівка, з якої виготовлений пакет, має у своєму складі поліпропілен з вмістом вторинної сировини, що обумовлено використанням полімерних матеріалів 3 міркувань зниження собівартості продукції та захисту навколишнього природного середовища. Однак, на нашу думку, зниження собівартості не повинно негативно впливати на якісні показники та безпечність продукції.

Запаковані тестові зразки м'ясопродуктів (рис. 8) були досліджені за структурно-механічними властивостями. Перевірені: зміна органолептичних показників до та після повторної термічної обробки (пастеризації), активність води, мікробіологічні показники, залежність даних показників від вмісту основної сировини в продукті.

Як зазначалось вище, різні виробники багатошарових пакувальних матеріалів (у вигляді пакетів або плівок) використовують різні технології виробництва своєї продукції, розподіл шарів, їх склад, товщину та інші параметри, які слід враховувати при виборі системи пакування, вимог до термінів і умов зберігання.

\section{Висновок}

У процесі дослідження пакувальних матеріалів визначено, що при розробленні пакувальних плівок для проведення повторної теплової обробки шляхом пастеризації необхідне використання багатошарових матеріалів з визначеним рівнем граничних температур.

Для виробництва м'ясопродуктів, що виробляються з використанням повторної стерилізації, в складі плівок необхідно використовувати EVOH і термостійкі фарби та клей.

Подальші дослідження будуть направлені на розроблення багатошарових пакувальних плівок для проведення стерилізації з межовими значеннями температур до $140^{\circ} \mathrm{C}$ для досягнення стерилізаційних ефектів і можливості зберігання продуктів 3 дотриманням рекомендацій консервного виробництва.

\section{Література}

1. Українець А.І. Інновації в технології зберігання і пакування харчових продуктів / А.I. Українець, В.М. Пасічний, А.І. Маринін, О.В. Храпачов // Техніка, енергетика, транспорт АПК. - Вінниця, 2016. —№ 2(94). - С. 41—45.

2. Храпачев O.B. Барьерная упаковка - блиц для технолога / О.В. Храпачев // Спайс. 2014. - № 9. - C. 16-17.

3. Dixon J. Packaging Materials: 9. Multilayer Packaging for Food and Beverages/ John Dixon. ILSI Europe Report Series. — Belgium : ILSI, July 2011:1 - 43.—Bibliogr.: P. 7-12.

4. Масліков М.М. Упаковка заморожених продуктів / М.М. Масліков // Мясное Дело. 2006. - № 5. - С. 30-32.

5. Пасічний В.М. Дослідження факторів пролонгації термінів зберігання м'ясних і м'ясомістких продуктів / В.М. Пасічний, А.М. Гередчук, О.О. Мороз, Ю.А. Ястреба // Наукові праці Національного університету харчових технологій. - 2015. - Т. 21, № 4. - С. $224-230$.

6. Robertson Gordon L. Food Packaging: Principles and Practice. 3td ed / Gordon L. Robertson. — by CRC Press, 2012. — 733 p. - Bibliogr. : P. $20-42$.

7. Мачинская $A$. PremiumPack: «Будущее - за экологичной упаковкой!» / Анна Мачинская // Мир Продуктов. - 2011. - № 6. - С. 38-39.

8. Пасічний В.M. Перспективи використання пакувальних матеріалів для термічної обробки м'яса та м'ясопродуктів / В.М. Пасічний, А.І. Українець, О.В. Храпачов, А.І. Маринін // Техніка, енергетика, транспорт АПК. — Вінниця, 2017. — № 2(97) — С. 71 -75. 